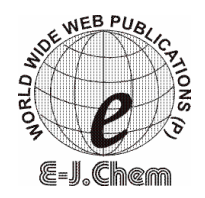

\title{
Synthesis, Physical Characterization and Biological Evaluation of Schiff Base $\mathrm{Cr}$ (III), Mn(III) and Fe(III) Complexes
}

\author{
GAJENDRA KUMAR, DHARMENDRA KUMAR ${ }^{\S}$, \\ SHOMA DEVI ${ }^{\#}$, AMIT KUMAR and RAJEEV JOHARI ${ }^{*}$ \\ Department of Chemistry, Meerut College, Meerut, (U.P)- 250001, India. \\ ${ }^{\S}$ Department of Chemistry, Vardhaman College, Bijnor (UP)- 246701, India. \\ \#Department of Life Science, Vardhaman College, Bijnor (UP) -246701, India. \\ gaj25chem@gmail.com
}

Received 11 December 2009; Accepted 7 February 2010

\begin{abstract}
M}$ (III) complexes with $\mathrm{Cr}, \mathrm{Mn}$ and $\mathrm{Fe}$ with Schiff base derived from 2-amino-4-ethyl-5-hydroxy benzaldehyde and oxocarbohydrazide were synthesized and characterized by several techniques using elemental analysis $(\mathrm{C}, \mathrm{H}, \mathrm{N})$, molar conductance measurements, magnetic measurements, electronic, mass and IR spectral studies. On the bases of these studies, a five coordinated square pyramidal geometry for all these complexes has been proposed and found to be potential antimicrobial agent. The Schiff base ligand and complexes were also tested for their antimicrobial activity (against the bacteria Escherichia coli, Staphylococcus aureus, Pseudomonas aeruginosa and Bacillus megaterium and the fungi Kluyveromyces fragilis, Rhodotorula rubra, Candida albicans and Trichoderma reesei) to assess their inhibiting potential. An attempt is also made to correlate the antimicrobial activity with geometry of the complexes. All complexes were found to be less active against the pathogens E.coli, S.aureus and P.aeruginosa. $\mathrm{Cr}(\mathrm{III})$ complex showed the best antimicrobial activity, but ligand alone was found to be active against the fungus T.reese $i$.
\end{abstract}

Keywords: $\mathrm{Co}(\mathrm{III}), \mathrm{Cr}(\mathrm{III})$ and $\mathrm{Fe}(\mathrm{III})$ Complexes, Schiff base, 2-Amino-4-ethyl-5-hydroxy benzaldehyde, Oxocarbohydrazide, Antimicrobial activity

\section{Introduction}

The field of Schiff base complexes was fast developing on account of the wide variety of possible structure for the ligands depending up on the aldehydes and amines. Many Schiff base 
and their complexes have been widely studied because of their industrial and biological applications ${ }^{1,2}$. Some Schiff base was tested for fungicidal activity which is related to their chemical structure ${ }^{3}$. Schiff base compound containing an amine group $(-\mathrm{RC}=\mathrm{N}-)$ are usually formed by the condensation of a primary amine with an active carbonyl. The cross linking agents can also be derived from metal complexes with $\mathrm{O}-\mathrm{N}-$ or $-\mathrm{S}$ ligands for example, the intra coordination salt such as salicylates, anthranilates and the aliphatic or aromatic amines can form strong five or six membered chelates rings which are able to produce the metal containing crosslinking agents with required properties ${ }^{4-7}$. Synthesis of oxovanadium(IV) complexes of the Schiff base derived by the condensation of 2aminobenzaldehyde with various diamines (1, 2-diaminoethane, 1, 2-diaminopropane, 1, 3-diaminopropane) and characterized by elemental analysis, spectral data and electrochemical studies ${ }^{8}$. The complexes of $\mathrm{Co}(\mathrm{II}), \mathrm{Ni}(\mathrm{II})$ and $\mathrm{Cu}(\mathrm{II})$ ions with the Schiff base derived from the condensation of salicylaldehyde and $o$-aminophenol or 2 -aminobenzoic acid were synthesized and characterized by using different techniques, in particular the elemental analysis, molar conductance measurements, IR and electronic spectra $^{9-10}$.

The aim of the present paper is to prepare, characterize and study the antimicrobial activity of the Schiff base complexes derived from oxocarbohydrazide and 2-amino-4-ethyl5-hydroxy benzaldehyde.

\section{Experimental}

All chemicals used in this work were analytical reagent grade (anhydrous). $\mathrm{CrCl}_{3}, \mathrm{MnCl}_{3}$ and $\mathrm{FeCl}_{3}$ were purchase from Aldrich (New Delhi, India) DMSO, DMF, ethanol were purchase from sigma (New Delhi, India) and 2-amino-4-ethyl-5-hydroxy benzaldehyde and oxocarbohydazide from Fluka (Mumbai, India).

\section{Synthesis of Schiff base}

The Schiff base (ligand) was prepared by mixing a warm dilute ethanol solution of oxocarbohydrazide $(5 \mathrm{mmol})$ with 2 -aminobenzaldehyde $(10 \mathrm{mmol})$ under reflux for two hours. The precipitate was then removed from the reaction mixture by filtration ${ }^{10,11}$, washed with ethanol and dried in desiccator over anhydrous $\mathrm{CaCl}_{2}$. The colour of the solid product was yellow (yield 65\%).<smiles>CCc1cc(N)c(/C=N/NC(=O)N/N=C/c2cc(O)c(C(C)(C)C)cc2N)cc1O</smiles>

Scheme 1. Synthesis of Schiff base ligand.

\section{Synthesis of complexes}

The Schiff base was taken in ethanol $\left(50 \mathrm{~cm}^{3}\right)$ and stirred gently for one hour to give homogeneous solution and added trivalent chromium, manganese or iron chlorides salts $\left(25 \mathrm{~cm}^{3}\right)$. The resulting solution was refluxed for 6-8 hours. The mixture was concentrated to half of its initial volume and kept in a desiccator for two days over anhydrous $\mathrm{CaCl}_{2}$. 
The complexes were then filtered, washed with ethanol and dried. The complexes are soluble in DMF and DMSO but are insoluble in other common organic solvent and water. They were thermally stable up to 523-553K and then decompose.

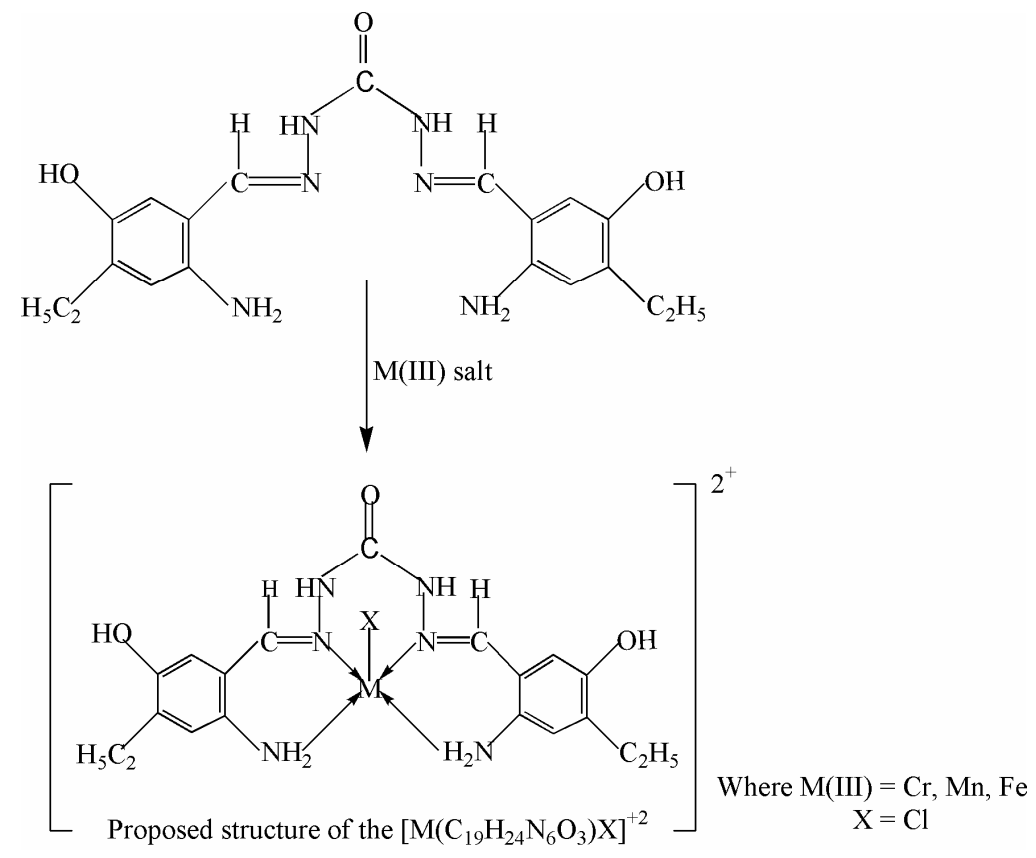

Scheme 2. Synthesis of the M(III) Schiff base complexes.

\section{Methods}

The microanalysis of $\mathrm{C}, \mathrm{H}$ and $\mathrm{N}$ were estimated by elemental analyzer (Perkin Elmer 2400), at SAIF, CDRI, Lucknow, India and the metal contents of Mn(III), Co(III) and $\mathrm{Cu}$ (III) was determined using atomic absorption spectrophotometer Perkin Elmer 5000. (See Table 1 containing also some physical properties of the prepared compounds). The conductivity was measured on digital conductivity meter (HPG system, G-3001) in DMSO at room temperature. The magnetic susceptibility measurements were carried out on vibrating sample magnetometer (Model PAR 155) at room temperature. Electronic spectra (in DMSO) were recorded on a Hitachi 330 spectrophotometer $\left(5815-32573 \mathrm{~cm}^{-1}\right)$. The IR spectra were performed using a FT-IR spectrophotometer Perkin Elmer 1650 in the range 4000-200 $\mathrm{cm}^{-1}$ using Nujol Mull (In Tables 1 and 2 molar conductivities, magnetic moments and spectral data are given). The FAB mass spectra (at room temperature) were recorded on VG-70-S mass spectrometer. The purity of the Schiff base and its complexes were confirmed also by TLC [microcrystalline cellulose (E. Merck) was used for the preparation of thin layer, complete separation was achieved with the solvent system acetone/conc. $\mathrm{HCl} /$ water $(86: 8: 7) . \mathrm{R}_{\mathrm{F}}$ values increase in the following order of $\mathrm{M}$ (II) complexes: $\mathrm{Mn}, \mathrm{Co}, \mathrm{Cu}(0.20,0.34,0.60)]$ and HPLC. The HPLC chromatographic apparatus consisted of a model waters 600 pump with waters 600 controller, waters 2996 photodiode array detector with UV detection $254 \mathrm{~nm}$, flow rate $1 \mathrm{~mL} / \mathrm{min}$ a discovery $\mathrm{C}_{8}, 15 \mathrm{~cm} \times 4.6 \mathrm{~mm}$ I.D, $5 \mu \mathrm{m}$ particles and mobile phase methanol: $25 \mathrm{~mm}$ $\mathrm{KH}_{2} \mathrm{PO}_{4}(20: 80) \mathrm{PH}=3$ techniques. 
Table 1. Elemental analysis in $\%$, molar conductance $\left(\Lambda_{\mathrm{M}}\right.$ in DMSO) in $\mathrm{S} \mathrm{cm}^{2} \mathrm{~mol}^{-1}$ and magnetic moment $\left(\mu_{\mathrm{eff}}\right)$ in $\mu_{\mathrm{B}}$ of the Schiff base ligand and its metal complexes.

\begin{tabular}{|c|c|c|c|c|c|c|c|c|c|}
\hline \multirow[b]{2}{*}{ Compounds $^{\mathrm{a}}$} & \multirow[b]{2}{*}{ Molecular formula } & \multirow[b]{2}{*}{ FW } & \multirow[b]{2}{*}{ Colour } & $\mathrm{C}$ & $\mathrm{H}$ & $\mathrm{N}$ & $\mathrm{M}$ & \multirow[t]{2}{*}{$\mu_{\text {eff }}$} & \multirow[t]{2}{*}{$\Lambda_{\mathrm{M}}$} \\
\hline & & & & $\begin{array}{l}\text { Calcu } \\
\text { (Found) }\end{array}$ & $\begin{array}{l}\text { Calcu } \\
\text { (Found) }\end{array}$ & $\begin{array}{l}\text { Calcu } \\
\text { (Found) }\end{array}$ & $\begin{array}{l}\text { Calcu } \\
\text { (Found) }\end{array}$ & & \\
\hline Ligand (HL) & $\mathrm{C}_{19} \mathrm{H}_{24} \mathrm{~N}_{6} \mathrm{O}_{3}$ & 384.209 & yellow & $\begin{array}{c}59.39 \\
(58.84)\end{array}$ & $\begin{array}{c}6.2 \\
(6.50)\end{array}$ & $\begin{array}{c}21.84 \\
(21.87)\end{array}$ & & & \\
\hline Cr complex & {$\left[\mathrm{Cr}\left(\mathrm{C}_{19} \mathrm{H}_{24} \mathrm{~N}_{6} \mathrm{O}_{3}\right) \mathrm{X}\right] \mathrm{X}_{2}$} & 542.56 & $\begin{array}{l}\text { greenish } \\
\text { yellow }\end{array}$ & $\begin{array}{c}42.06 \\
(42.12)\end{array}$ & $\begin{array}{c}4.42 \\
(4.45)\end{array}$ & $\begin{array}{c}15.48 \\
(15.45)\end{array}$ & $\begin{array}{c}9.57 \\
(9.49)\end{array}$ & 4.35 & 58.8 \\
\hline Mn complex & {$\left[\mathrm{Mn}\left(\mathrm{C}_{19} \mathrm{H}_{24} \mathrm{~N}_{6} \mathrm{O}_{3}\right) \mathrm{X}\right] \mathrm{X}_{2}$} & 545.50 & dark & $\begin{array}{c}41.83 \\
(41.75)\end{array}$ & $\begin{array}{c}4.39 \\
(4.41)\end{array}$ & $\begin{array}{c}15.39 \\
(15.35)\end{array}$ & $\begin{array}{c}10.07 \\
(10.15)\end{array}$ & 4.85 & 40.00 \\
\hline Fe complex & {$\left[\mathrm{Fe}\left(\mathrm{C}_{19} \mathrm{H}_{24} \mathrm{~N}_{6} \mathrm{O}_{3}\right) \mathrm{X}\right] \mathrm{X}_{2}$} & 546.41 & $\begin{array}{l}\text { orange } \\
\text { Red }\end{array}$ & $\begin{array}{c}41.76 \\
(41.75)\end{array}$ & $\begin{array}{c}4.39 \\
(4.35) \\
\end{array}$ & $\begin{array}{c}15.37 \\
(15.40)\end{array}$ & $\begin{array}{c}10.22 \\
(10.25)\end{array}$ & 5.78 & 32.50 \\
\hline
\end{tabular}

${ }^{a} \mathrm{HL}=$ free Schiff base $\mathrm{C}_{19} \mathrm{H}_{24} \mathrm{~N}_{6} \mathrm{O}_{2} \mathrm{~S}$.

Table 2. IR spectral bands position $/ \mathrm{cm}^{-1}$ and electronic spectral data (in DMSO) $\mathrm{cm}^{-}{ }^{1}$ of the Schiff base ligand and its metal complexes.

\begin{tabular}{lcccccccc}
\hline $\begin{array}{l}\text { Compounds } \\
\text { maxima }\end{array}$ & $v\left(\mathrm{NH}_{2}\right)$ & $v(\mathrm{C}=\mathrm{N})$ & $v(\mathrm{C}=\mathrm{O})$ & $v(\mathrm{M}-\mathrm{Cl})$ & $v(\mathrm{M}-\mathrm{N})$ & $-\mathrm{OH}$ str & $-\mathrm{OH}$ ben & UV-Vis \\
\hline $\begin{array}{l}\text { Ligand (HL) } \\
\text { Cr(III) }\end{array}$ & 3250 & 1560 & 1696 & 295 & 410 & 3327 & 1350 & 27027 \\
$\begin{array}{l}\text { complex } \\
\begin{array}{l}\text { Mn(III) } \\
\text { complex }\end{array}\end{array}$ & 3280 & 1530 & 1715 & 310 & 400 & 3292 & 1352 & $8950-9300$ \\
$\begin{array}{l}\text { Fe(III) } \\
\text { complex }\end{array}$ & 3310 & 1560 & 1705 & 290 & 440 & 3375 & 1380 & $22200-22575$ \\
\hline
\end{tabular}

${ }^{a} \mathrm{HL}=$ free Schiff base $\mathrm{C}_{19} \mathrm{H}_{24} \mathrm{~N}_{6} \mathrm{O}_{2} \mathrm{~S}, \quad \mathrm{U}$-vis ( extinction coefficients are given in parentheses, $\mathrm{dm}^{3}$ $\mathrm{mol}^{-1} \mathrm{~cm}^{-1}$ 1) for $\mathrm{HL}$ (35800), Cr(III) complex $(24500,8200), \mathrm{Mn}(\mathrm{III})$ complex $(32400,12600)$ and $\mathrm{Fe}$ (III) complex (18300, 8900).

\section{Antimicrobial activity}

The antibacterial and antifungal activities of the newly synthesized compounds were evaluated by agar well diffusion method ${ }^{12}$. All the microbial cultures were adjusted to 0.5 McFarland standards, which is visually comparable to a microbial suspension containing approximately $1.5 \times 10^{8} \mathrm{cfu} / \mathrm{mL}^{13} .20 \mathrm{~mL}$ of agar media was poured into each Petri plate and plates were swabbed with $100 \mu \mathrm{L}$ inocula of the test microorganisms and kept 15 min for adsorption. Using sterile cork borer of $8 \mathrm{~mm}$ diameter, wells were bored into the seeded agar plates and these were loaded with a $100 \mathrm{~mL}$ volume with concentration of $1.0 \mathrm{mg} / \mathrm{mL}$ of each compound dissolved in the dimethylsulphoxide (DMSO). All the plates were incubated at $300 \mathrm{~K}$ for $24 \mathrm{~h}$. Antimicrobial activity of all the synthesized compounds was evaluated by measuring the zone of growth inhibition against the test organisms with zone reader (Hi antibiotic zone scale). The medium with dimethylsulphoxide (DMSO) as solvent was used as a negative control whereas media with Ciprofloxacin (standard antibiotic) and Griseofulvin (standard antifungal drug) were used as positive control. The experiments were performed in triplicates.

The ligand HL and its $\mathrm{Cr}(\mathrm{III}), \mathrm{Mn}(\mathrm{III})$ and $\mathrm{Fe}(\mathrm{III})$ complexes were tested for their antibacterial and antifungal activity against the bacteria: Escherichia coli, Staphylococcus aureus, Pseudomonas aeruginosa and Bacillus megaterium and the fungi: Kluyveromyces fragilis, Rhodotorula rubra, Candida albicans and Trichoderma reesei procured from Microbial Type Collection and Gene Bank, Institute of Microbial Technology (IMTECH), Chandigarh, India. 


\section{Results and Discussion}

The elemental analysis $(\mathrm{C}, \mathrm{H}, \mathrm{N}, \mathrm{M})$ data of the metal chelates showed that they may be represented by the formula $\left[\mathrm{M}\left(\mathrm{C}_{19} \mathrm{H}_{24} \mathrm{~N}_{6} \mathrm{O}_{3}\right) \mathrm{X}\right] \mathrm{X} 2,(\mathrm{M}(\mathrm{III})=\mathrm{Cr}, \mathrm{Mn}$ and $\mathrm{Fe} ; \mathrm{X}=\mathrm{Cl})$. The purity of the Schiff base and its complexes was also confirmed by TLC and HPLC techniques.

The measurements of molar conductance in DMSO show that these chelates are 1:2 type of electrolytes (conductance values were $30-60 \mathrm{~S} \mathrm{~cm}^{2} \mathrm{~mol}^{-1}$, whereas the literature range was 30-180 $\left.\mathrm{Scm}^{2} \mathrm{~mol}^{-1}\right)^{14}$. The tests for anions are positive before decomposing and after decomposing the chelates with concentrated $\mathrm{HNO}_{3}$ showing their presence outside as well as inside the coordination sphere. Several attempts failed to obtain a single crystal suitable for $\mathrm{x}$-ray crystallography. However, the analytical, spectroscopic and magnetic data enable us to predict the possible structure of the synthesized complexes. The low molar conductance of the complexes might arise due to large size of the cation coordination sphere, which might have low ionic mobility, the value of molar conductance's suggest that complexes are electrolytes and that chloride is present as the counter ion.

The IR spectra provide valuable information regarding the nature of functional group attached to the metal atom. The presence of a single medium band in the region $3250-3330 \mathrm{~cm}^{-}$ ${ }^{1}$ in the complexes may be assigned to N-H stretching vibrations ${ }^{15,16}$. It was noted that a pair of bands corresponding to ${ }_{v}\left(\mathrm{NH}_{2}\right)$ at $3245 \mathrm{~cm}^{-}{ }^{1}$ and $3309 \mathrm{~cm}^{-}{ }^{1}$ are present in the spectra of the thiocarbohydrazide. The value of ${ }_{v}(\mathrm{C}=\mathrm{N})$ stretching vibration is found lower $(1520-1560$ $\left.\mathrm{cm}^{-1}\right)$ than the expected value $\left(1580-1650 \mathrm{~cm}^{-}\right)$. This may be explained on the basis of a drift of lone pair density of azomethine nitrogen towards the metal atom ${ }^{17,18}$ indicating that coordination takes place through nitrogen of $(\mathrm{C}=\mathrm{N})$ groups. The bands present in the range 3020-3040 cm- ${ }^{1}$ may be assigned due to $(\mathrm{C}-\mathrm{H})$ stretching vibrations of benzil and naphthalene rings ${ }^{19}$. The $\mathrm{C}-\mathrm{N}$ stretching was in the range $1000-1300 \mathrm{~cm}^{-}{ }^{1}$. The band near $1700 \mathrm{~cm}^{-}{ }^{1}$ in oxocarbohydrazide may be assigned to free ${ }_{v}(\mathrm{C}=\mathrm{O})$. The band at $3292-3438 \mathrm{~cm}^{-}{ }^{1}$ is due to the presence of $-\mathrm{OH}$ group in the complexes. This band is also present in the spectra of all the complexes, which indicate that oxygen is not coordinating to the metal atom ${ }^{20,21}$. The far IR spectra show bands in the region $420-450 \mathrm{~cm}^{-1}$ corresponding to ${ }_{v}(\mathrm{M}-\mathrm{N})$ vibrations ${ }^{22-24}$. The presence of bands in all complexes in the region $420-450 \mathrm{~cm}^{-}{ }^{1}$ originates from the (M-N) azomethine vibrational modes and identifies coordination of azomethine nitrogen ${ }^{25}$. The bands present at $290-310 \mathrm{~cm}^{-1}$ may be assigned to $v(\mathrm{M}-\mathrm{Cl})$ vibrations ${ }^{26,27}$.

The FAB mass spectra of ligand, $\mathrm{Cr}(\mathrm{III}), \mathrm{Mn}(\mathrm{III})$ and $\mathrm{Fe}(\mathrm{III})$ complexes have been recorded. All the spectra exhibit parent peaks due to molecular ions $\left(\mathrm{M}^{+}\right)$. The proposed molecular formula of these complexes was confirmed by comparing their molecular formula weights with $m / z$ values. The molecular ion $\left(\mathbf{M}^{+}\right)$peaks obtained for various complexes are as follows: $m / z 384$ (ligand), $m / z 542$ (Cr(III) complex), $m / z 545$ (Mn(III) complex), $m / z 546$ (Fe(III) complex) These data are in good agreement with the proposed molecular formula for these complexes i.e. $\left[\mathrm{M}\left(\mathrm{C}_{19} \mathrm{H}_{24} \mathrm{~N}_{6} \mathrm{O}_{3}\right) \mathrm{X}\right] \mathrm{X}_{2}$. Where $\mathrm{M}=\mathrm{Cr}(\mathrm{III}), \mathrm{Mn}(\mathrm{III})$ and $\mathrm{Fe}(\mathrm{III})$ and $\mathrm{X}=\mathrm{Cl}^{-}$. In addition to the peaks due to the molecular ions, the spectra exhibit peaks assignable to various fragments arising from the thermal cleavage of the complexes. The peak intensity suggested the stability of the fragments.

The electronic spectra of the Schiff base and its complexes were recorded in DMSO. The absorption spectra of free ligand consist of an intense bands centered at $370 \mathrm{~nm}\left(27027 \mathrm{~cm}^{-1}\right)$ attributed to $\mathrm{n} \rightarrow \pi^{*}$ transition of the oxo group. Another intense band in higher energy region of the spectra of the free ligand was related to $n \rightarrow \pi^{*}$ transition of benzene rings ${ }^{21}$. 
Magnetic moments of $\mathrm{Cr}(\mathrm{III})$ complex was found $4.35 \mu_{\mathrm{B}}$ at room temperature which is close to the predicted values for three unpaired electrons in the metal ion ${ }^{28}$. The electronic spectrum of Cr(III) complex showed bands in the range 8950-9310 $\mathrm{cm}^{-}{ }^{1}$. The spectral bands are consistent with that of five-coordinated $\mathrm{Cr}(\mathrm{III})$ complex, whose structure has been confirmed with the help of $\mathrm{x}$-ray measurements ${ }^{29}$. On the basis of the analytical data, spectral studies and electrolytic nature of the complex, a square-pyramidal geometry may be assigned for this complex ${ }^{30}$. The spectral bands may be assigned as: ${ }^{4} \mathrm{~B}_{1} \rightarrow{ }^{4} \mathrm{E}^{\mathrm{a}}{ }^{4} \mathrm{~B}_{1} \rightarrow{ }^{4} \mathrm{~B}_{2}$, ${ }^{4} \mathrm{~B}_{1} \rightarrow{ }^{4} \mathrm{~A}_{1}$ and ${ }^{4} \mathrm{~B}_{1} \rightarrow{ }^{4} \mathrm{E}^{\mathrm{b}}$.

The magnetic moment of $\mathrm{Mn}(\mathrm{III})$ complex was $4.85 \mu_{\mathrm{B}}$ which indicates the high spin $\mathrm{d}^{4}$ system $^{28}$. The electronic spectra of manganese complex show three d-d band which lays in the range 12250-12590 $\mathrm{cm}^{-1}$ and may be assigned to charge transfer transitions. The spectra resemble to those reported for five coordinate square pyramidal manganese(III) complexes ${ }^{30}$. This is further supported by the presence of the broad ligand field band at $20400 \mathrm{~cm}^{-}{ }^{1}$. The various bands may be assigned as follows: ${ }^{5} \mathrm{~B}_{1} \rightarrow{ }^{5} \mathrm{~A}_{1},{ }^{5} \mathrm{~B}_{1} \rightarrow{ }^{5} \mathrm{~B}_{2}$ and ${ }^{4} \mathrm{~B}_{1} \rightarrow{ }^{5} \mathrm{E}$. The band assignment in single electron transition may be made as: $\mathrm{d}_{\mathrm{z}}{ }^{2} \rightarrow \mathrm{d}_{\mathrm{x}}{ }^{2-}{ }_{\mathrm{y}}{ }^{2}, \mathrm{~d}_{\mathrm{xy}} \rightarrow \mathrm{d}_{\mathrm{x}}{ }^{2-}{ }_{\mathrm{y}}{ }^{2}$ and $\mathrm{d}_{\mathrm{xy}}$, $\mathrm{d}_{\mathrm{yz}} \rightarrow \mathrm{d}_{\mathrm{x}}{ }^{2-}{ }_{\mathrm{y}}{ }^{2}$, respectively, in order of increasing energy. However, the complexes do not have idealized $\mathrm{C}_{4 \mathrm{~V}}$ symmetry.

The magnetic moment of $\mathrm{Fe}(\mathrm{III})$ complex was $5.78 \mu_{\mathrm{B}}$ corresponding to the five unpaired electrons and is close to the predicted high spin values for this metal ion ${ }^{28}$. The electronic spectra of $\mathrm{Fe}(\mathrm{III})$ complex show various bands in the range $9820-9970 \mathrm{~cm}^{-}{ }^{1}$ and are consistent with the range of spectral bands reported for five coordinate square pyramidal $\mathrm{Fe}(\mathrm{III})$ complex ${ }^{31}$. The various bands can be assigned as: $\mathrm{d}_{\mathrm{xy}} \rightarrow \mathrm{d}_{\mathrm{xz}}, \mathrm{d}_{\mathrm{yz}}$ and $\mathrm{d}_{\mathrm{xy}} \rightarrow \mathrm{d}_{\mathrm{z}}{ }^{2}$. Any attempt to make accurate assignment is difficult due to interactions of the metal-ligand $\pi$-bond systems lifting the degeneracy of the $\mathrm{d}_{\mathrm{xz}}$ and $\mathrm{d}_{\mathrm{yz}}$ pair.

Based on various studies like elemental analysis, conductance measurements, magnetic susceptibilities, IR, electronic and mass spectral studies the structure shown in Scheme 2 may be proposed for all of the complexes.

The results showed (Table 3) that HL (ligand) exhibits moderate activity against all tested bacteria and Candida albicans fungus. HL showed high antifungal activity against Kluyveromyces fragilis and Trichoderma reesei but no activity against Rhodotorula rubra. $\mathrm{Cr}(\mathrm{III})$ complex showed high antibacterial and antifungal activity against Bacillus megaterium, Kluyveromyces fragilis, Rhodotorula rubra and Candida albicans, moderate activity against Escherichia coli, Staphylococcus aureus and Pseudomonas aeruginosa, but no activity against the Trichoderma reesei. $\mathrm{Mn}$ (III) complex exhibited moderate activity against Pseudomonas aeruginosa and Bacillus megaterium, was highly effective against the Kluyveromyces fragilis, Candida albicans and Trichoderma reesei but showed no activity against the Escherichia coli, Staphylococcus aureus and Rhodotorula rubra. Fe(III) complex exhibited moderate activity against Staphylococcus aureus, Pseudomonas aeruginosa, Bacillus megaterium and Trichoderma reesei, higher effect against Kluyveromyces fragilis and Candida albicans, but no activity against Escherichia coli and Rhodotorula rubra microorganisms.

Antibacterial and antifungal activity of the ligand and its metal complexes is compared with the standard drug Ciprofloxacin and Griseofulvin. The variation in the activity of different metal complexes against different microorganisms depends on their impermeability of the cell or the differences in ribosomes in microbial cell ${ }^{32}$. The lipid membrane surrounding the cell favors the passage of any lipid soluble materials and it is known that liposolubility is an important factor controlling antimicrobial activity ${ }^{33,34}$. 
In the present study low activity of the some metal complexes is may be due to their low lipophilicity, because of which penetration of the complex through the lipid membrane was decreased and hence, they could neither block nor inhibit the growth of the microorganism.

Table 3. Antibacterial and antifungal activity of the standards, solvent, ligand and its metal complexes.

\begin{tabular}{|c|c|c|c|c|c|c|c|c|}
\hline \multirow[b]{2}{*}{ Compounds ${ }^{\mathrm{a}}$} & \multicolumn{4}{|c|}{ Bacterial inhibition zone/mm } & \multicolumn{4}{|c|}{ Fungi inhibition zone/mm } \\
\hline & 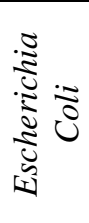 & 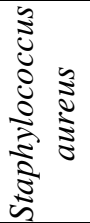 & 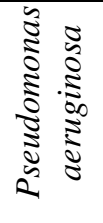 & 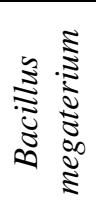 & 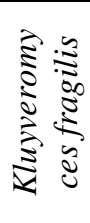 & 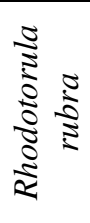 & 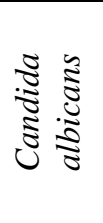 & 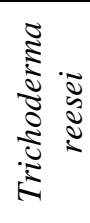 \\
\hline Ligand (HL) & 7 & 7 & 7 & 8 & 12 & 0 & 9 & 14 \\
\hline Cr Complex & 9 & 8 & 7 & 16 & 18 & 16 & 12 & 0 \\
\hline Mn Complex & 0 & 0 & 9 & 7 & 10 & 0 & 15 & 12 \\
\hline Fe Complex & 0 & 8 & 9 & 7 & 15 & 0 & 12 & 7 \\
\hline Ciprofloxacin & 24 & 20 & 22 & 24 & - & - & - & 1 \\
\hline Griseofulvin & - & - & - & - & 24 & 24 & 24 & 23 \\
\hline DMSO (Control) & 0 & 0 & 0 & 0 & 0 & 0 & 0 & 0 \\
\hline
\end{tabular}

\section{Conclusion}

${ }^{a} \mathrm{HL}=$ free Schiff base $\mathrm{C}_{19} \mathrm{H}_{24} \mathrm{~N}_{6} \mathrm{O}_{2} \mathrm{~S}$.

The analytical data show the presence of one metal ion per ligand molecule and suggest a mononuclear structure for the complexes $\left[\mathrm{M}\left(\mathrm{C}_{19} \mathrm{H}_{24} \mathrm{~N}_{6} \mathrm{O}_{3}\right) \mathrm{X}\right] \mathrm{X}_{2}$. The electronic spectral data is in the favor of square pyramidal geometry of the complexes. The ligand and its $\mathrm{Cr}(\mathrm{III})$, $\mathrm{Mn}(\mathrm{III})$ and $\mathrm{Fe}(\mathrm{III})$ complexes were tested for antimicrobial activity against some pathogens. All the complexes were found to be less active against the bacteria E.coli, S.aureus and P.aeruginosa, whereas $\mathrm{Cr}(\mathrm{III})$ complex showed the best antimicrobial activity against the bacterium B.megaterium and the fungi K.fragilis and R.rubra. The free ligand $\left(\mathrm{C}_{19} \mathrm{H}_{24} \mathrm{~N}_{6} \mathrm{O}_{3}\right)$ was found to be active against the fungus T.reesei.

\section{Acknowledgment}

The authors express their sincere thank to the head from Department of Chemistry, Principal and College Managing Board of Vardhaman College, Bijnor, India for their encouragement and providing research facilities and to CDRI Lucknow and IIT Roorkee for providing mass, electronic and IR spectral data.

\section{References}

1. El-Borae H A, J Therm Anal Cal., 2005, 81, 339.

2. Zaki Z M, Haggag S S and Sayed A A, Spectrosc Lett., 1998, 31, 757.

3. Al-Shiri A S M and Abdel-Fattah H M, J Therm Anal Cal., 2003, 71, 643.

4. Kurnoskin A V, J M S Rev Macromol Chem Phys., 1996, C36(3), 457.

5. Kurnoskin A V, Polym Compos., 1993, 14(6), 481.

6. Kurnoskin A V, Polymer, 1993, 34(5), 1060.

7. Kurnoskin A V, Ind Eng Chem Res., 1992, 31, 524.

8. Canpolat E and Kaya M, J Coord Chem., 2004, 57(14), 1217.

9. Elzahany E A, Hegab K H, Khalil S K H and Youssef N S, Aust J Basic Appl Sci., 2008, 2(2), 210. 
10. Morad F M, El-ajaily M M and Ben Gweirif S, J Science and its Applications, 2007, 1(1), 72 .

11. Rajave R, Vadivu M S and Anitha C, E Journal of Chemistry, 2008, 5, 620.

12. Ahmad I and Beg A Z, J Ethnopharmacol., 2001, 74, 113.

13. Andrews J M, J Antimicrob Chemother., 2001, 48, 5.

14. Kumar R and Singh R, Turk J Chem., 2006, 30, 77.

15. Shakir M, Nasman O S M and Varkey S P, Polyhedron, 1996, 15, 309.

16. Bain G A, West D X, Krejci J, Martinez J V, Ortega S H and Toscano R A, Polyhedron, 1997, 16, 855.

17. Chandra S and Sharma S D, Transition Met Chem., 2002, 27, 732.

18. Lodeiro C, Basitida R, Bertolo E, Macias A and Rodriguez R, Transition Met Chem., 2003, 28, 388.

19. Singh D P, Kumar R, Malik V and Tyagi P, Transition Met Chem., 2007, 32, 1051.

20. Mikhailov O V, Kazymova M R, Shumilova T A and Solovieva S.S, Transition Met Chem., 2004, 20, 732.

21. Chandra S and Thakur S, Transition Met Chem., 2004, 29, 925.

22. Shakir M, Nasman O S M and Varkey S P, Polyhedron, 1996, 15, 309.

23. Shakir M, Islam KS, Mohamed A K, Shagufa M and Hasan S S, Transition Met Chem., 1999, 24, 577.

24. Chandra S and Kumar R, Transition Met Chem., 2004, 29, 269.

25. Rana VB, Singh D P, Singh P and Teotia M P, Transition Met Chem., 1982, 7, 174.

26. Shakir M, Islam KS, Mohamed A K and Jahn N, Transition Met Chem., 1997, 22, 189.

27. Khan T A, Hasan S S, Varkey S P, Rather M A, Jahan N and Shakir M, Transition Met Chem., 1997, 22, 4.

28. Figgis B N and Lewis J, Prog Inorg Chem., 1965, 6, 37.

29. Wood J S, Prog Inorg Chem., 1972, 16, 227.

30. Singh D P and Rana V B, Polyhedron, 1995, 14, 2901.

31. Lever A B P, Inorganic Electronic Spectroscopy, Elsevier, Amsterdam, 1984, $2^{\text {nd }}$ Ed.

32. Sengupta S K, Pandey O P, Srivastava B K and Sharma V K, Transition Met Chem., 1998, 23, 349.

33. Parekh J, Inamdhar P, Nair R, Baluja S and Chandra S, J Serb Chem Soc., 2005, 70, 116.

34. Vaghasia Y, Nair R, Soni M, Baluja S and Chandra S, J Serb Chem Soc., 2004, 69, 991. 


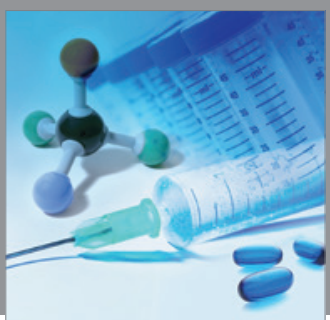

International Journal of

Medicinal Chemistry

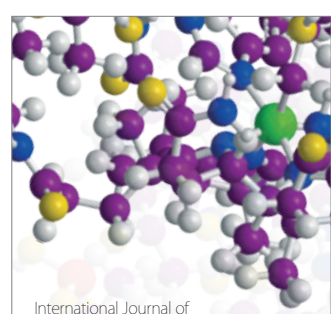

Carbohydrate Chemistry

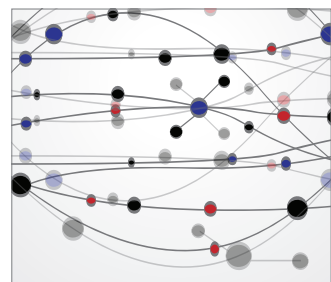

The Scientific World Journal
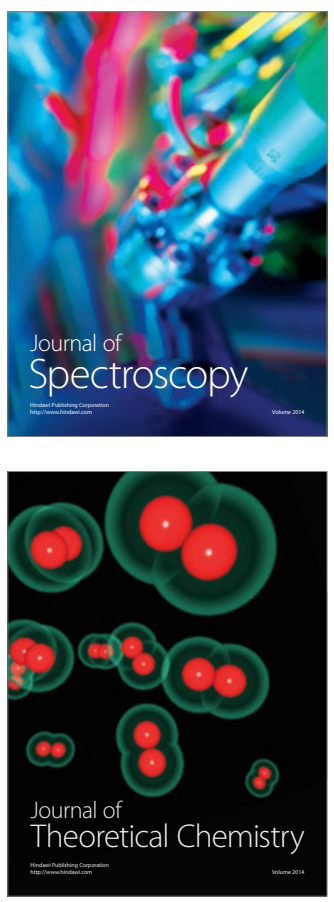
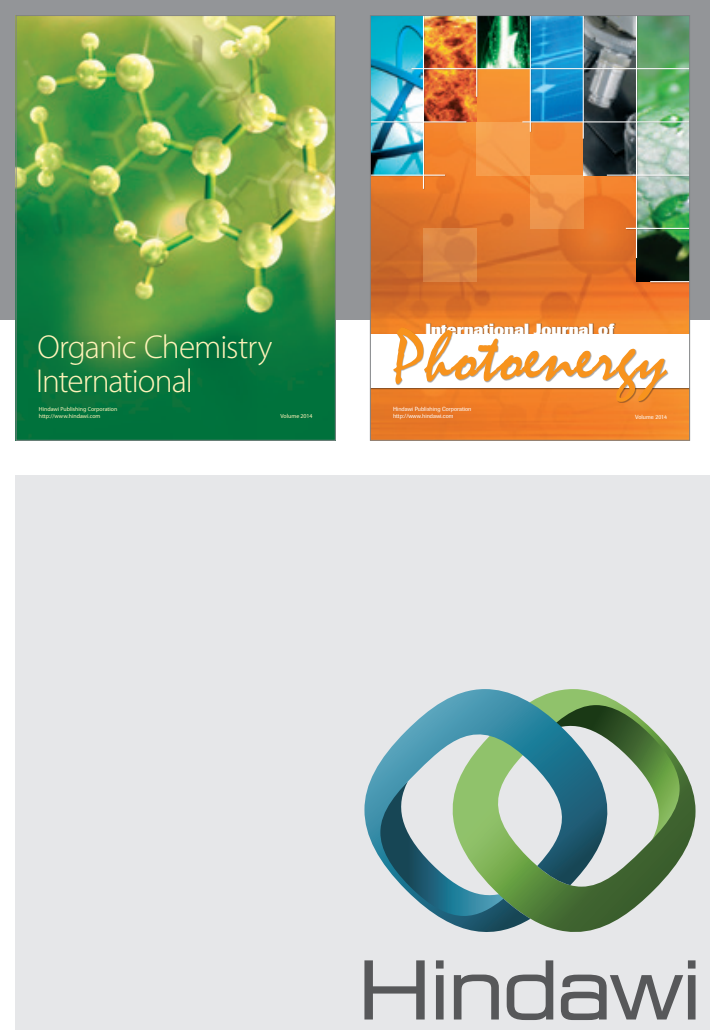

Submit your manuscripts at

http://www.hindawi.com
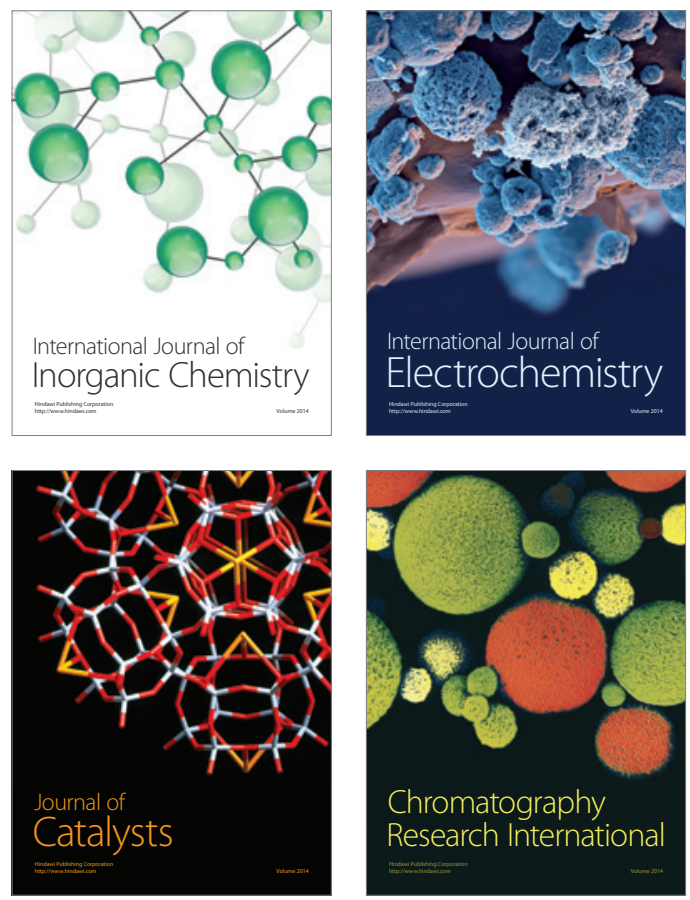
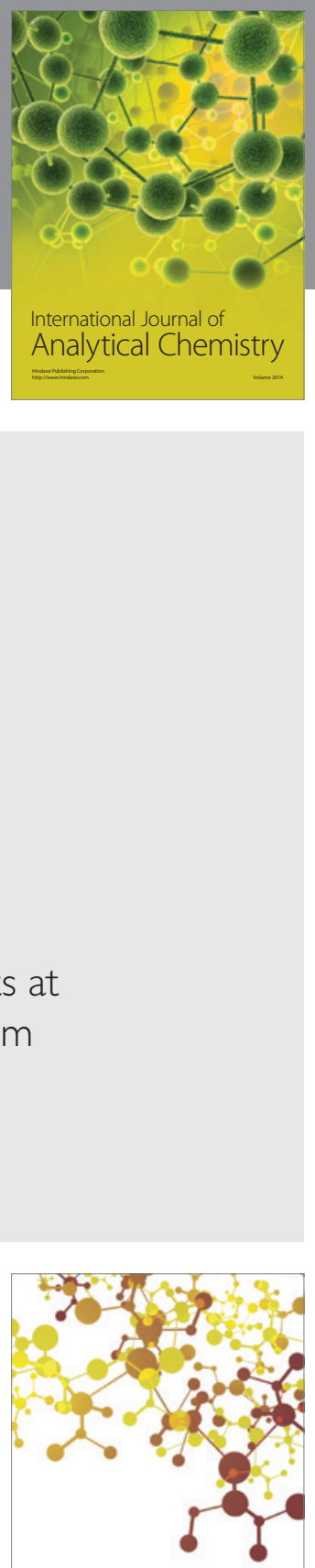

Journal of

Applied Chemistry
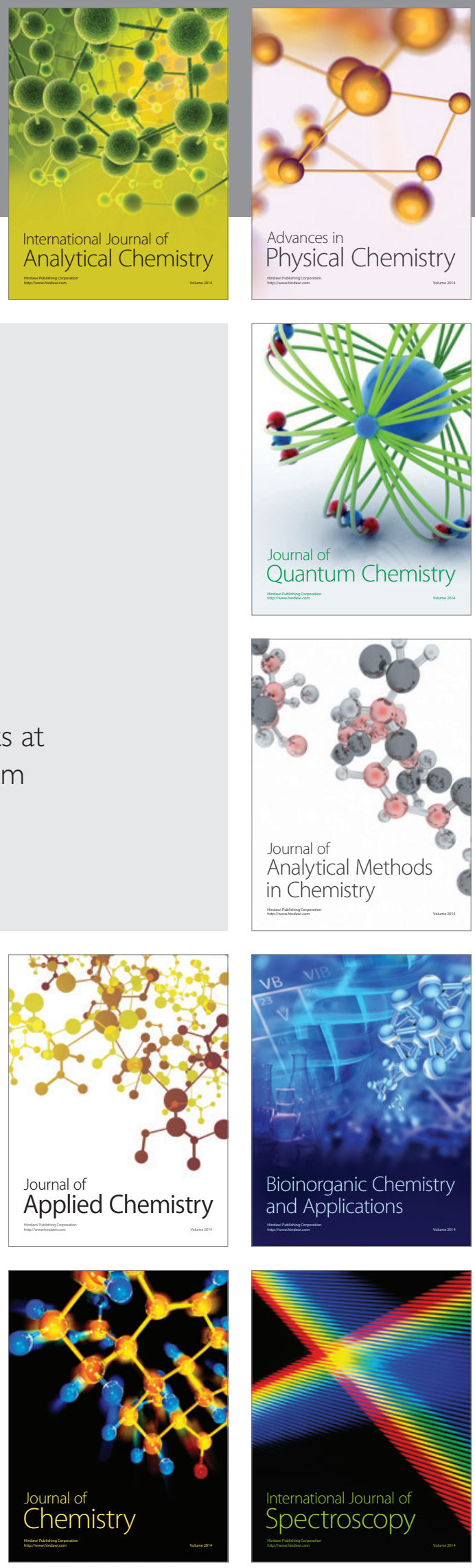